\title{
Penerapan Model Pembelajaran Resource Based Learning (RBL) Dalam Upaya Meningkatkan Kemampuan Penguasaan Konsep IPA
}

\author{
Muldiyana Nugraha ${ }^{1}$ \\ ${ }^{1}$ SMP Negeri Satu Atap Cikulur Kabupaten Lebak, Banten
}

\begin{tabular}{l} 
ARTICLE INFO \\
\hline Article History: \\
Received 25.01 .2018 \\
Received in revised \\
form 02.03 .2018 \\
Accepted 20.03.2018 \\
Available online \\
20.04.2018
\end{tabular}

\begin{abstract}
The study is aims to determine the improvement of the ability mastery of science concept by applying Resource Based Learning (RBL) learning model. The method used in this research is a classroom action research method consisting of three cycles, where in each cycle there are two meetings except in cycle III only one meeting. Resource Based Learning (RBL) learning model can improve students' mastery of science concept of SMPN 3 Satap Cikulur. The improvement of students' mastery of science is obtained from the results of data on cycle I activity that obtained an average score reached 67,88 and students who got the complete criteria of 19 students, in the cycle II reached an average score of 74,69 and students who received the complete criteria of 29 students, in the cycle III reached an average score of 82,69 and students who received the complete criteria of 34 students. From the results of the cycle that has been done the classroom action research activities using RBL learning model is said to work because the completeness of learning criteria reach $70 \%$. It is seen in the third cycle that reaches an average value of 82,69 and students who get the complete study criteria is 34 students means $85 \%$ of 40 students.
\end{abstract}

Keywords:

Learning Model, RBL, Science.

DOI: $10.30653 / 003.201841 .45$

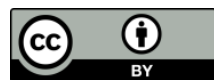

This is an open access article distributed under the terms of the Creative Commons Attribution 4.0 International License, which permits unrestricted use, distribution, and reproduction in any medium, provided the original work is properly cited. @ 2018 Muldiyana Nugraha.

\section{PENDAHULUAN}

Pendidikan merupakan investasi yang utama sekaligus merupakan isu sentral bagi setiap bangsa, apalagi bagi bangsa yang sedang berkembang yang giat membangun negaranya seperti halnya di negara Indonesia. Pembangunan hanya dapat dilakukan oleh manusia yang dipersiapkan untuk hal tersebut melalui pendidikan. Mutu pendidikan banyak bergantung kepada mutu guru dalam membimbing proses pembelajaran.

Proses pembelajaran merupakan suatu kegiatan mendidik siswa ke arah yang lebih baik. Peningkatan mutu pembelajaran itu sangat ditentukan oleh berbagai kondisi, baik kondisi intern maupun kondisi ekstern sekolah itu sendiri. Proses belajar mengajar yang baik didasari oleh adanya hubungan interpersonal yang baik antara siswa dengan guru, siswa dengan siswa, dan siswa dengan guru menduduki posisi penting bagi terbentuknya kondisi sosio emosional. Penelitian menunjukkan bahwa lingkungan sosial atau suasana kelas adalah penentu psikologis utama yang mempengaruhi belajar akademis (Welberg \& Greenb dalam DePorter, 2007).

${ }^{1}$ Corresponding author's address: SMP Negeri 3 Satu Atap Cikulur, Lebak, Banten, Indonesia e-mail: edomuldynugraha@gmail.com 
Lemahnya proses pembelajaran yang dikembangkan guru dewasa ini, merupakan salah satu masalah yang dihadapi di dunia pendidikan Indonesia. Proses pembelajaran yang terjadi di dalam kelas dilaksanakan sesuai dengan kemampuan dan selera guru. Kenyataanya kemampuan guru dalam pengelolaan pembelajaran tidak merata sesuai dengan latar belakang pendidikan guru serta motivasi dan keilmuan mereka terhadap profesinya. Hal ini ditegaskan pula oleh Sanjaya (2008) ada guru yang dalam melaksanakan pengelolaan pembelajarannya dilakukan bersungguhsungguh melalui perencanaan yang matang, dengan memanfaatkan seluruh sumber daya yang ada dalam memperhatikan taraf perkembangan intelektual dan perkembangan psikologi belajar peserta didik. Guru yang demikian akan dapat menghasilkan kualitas lulusan yang lebih tinggi dibandingkan dengan guru yang dalam pengelolaan pembelajarannya dilakukan tanpa mempertimbangkan berbagai faktor yang dapat mempengaruhi keberhasilan proses pembelajaran. Salah satu mata pelajaran pokok dalam proses pembelajaran di Sekolah Menengah Pertama (SMP) adalah Ilmu Pengetahuan Alam (IPA) atau sains yang merupakan suatu kumpulan pengetahuan yang tersusun secara sistematis, dan dalam penggunaannya secara umum terbatas pada gejalagejala alam. Perkembangan IPA selanjutnya tidak hanya ditandai oleh adanya kumpulan fakta saja, tetapi juga ditandai oleh munculnya "metode ilmiah" (scientific methods) yang terwujud melalui suatu rangkaian "kerja ilmiah" (working scientifically), nilai dan "sikap ilmiah" (scientific attitudes).

IPA berkaitan dengan cara mencari tahu tentang gejala alam secara sistematik, sehingga IPA bukan hanya penguasaan kumpulan pengetahuan yang berupa fakta-fakta, konsep-konsep, atau prinsipprinsip saja tetapi juga merupakan suatu proses penemuan. Pendidikan IPA diharapkan dapat menjadi wahana bagi siswa untuk mempelajari diri sendiri dan alam sekitar, serta prospek pengembangan lebih lanjut dan menerapkannya dalam kehidupan sehari-hari. Proses pembelajarannya menekankan pada pemberian pengalaman langsung untuk mengembangkan kompetensi agar siswa mampu menjelajahi dan memahami alam sekitar secara alamiah. Pendidikan IPA diarahkan untuk mencari tahu dan berbuat sehingga dapat membantu siswa untuk memperoleh pemahaman dan kemampuan penguasaan konsep yang lebih mendalam tentang alam sekitar.

Jadi pada hakekatnya pembelajaran IPA mencakup proses, produk dan sikap. Namun, jika dicermati pembelajaran IPA cenderung menekankan pada aspek produk, dimana fakta, hukum dan teori mendapat porsi yang dominan, sehingga aspek proses dan sikap kurang mendapat perhatian. Selain itu pembelajaran IPA dikembangkan untuk mengembangkan proses berpikir, namun selama ini pengembangannya hanya pada kemampuan berpikir tingkat rendah. Hal ini dikuatkan oleh Dasar Pemikiran yang ditulis pada Panduan Seminar Sehari Hasil Studi Internasional Prestasi Siswa Indonesia dalam Bidang IPA, Sains, dan Membaca, yang menyebutkan bahwa salah satu sebab rendahnya mutu lulusan adalah belum efektifnya proses pembelajaran. Proses pembelajaran selama ini masih terlalu berorientasi terhadap penguasaan teori dan hafalan dalam semua bidang studi yang menyebabkan kemampuan belajar siswa menjadi terhambat. Metode pembelajaran yang terlalu berorientasi kepada guru (teacher centered) cenderung mengabaikan hak-hak dan kebutuhan, serta pertumbuhan dan perkembangan anak, sehingga proses pembelajaran yang menyenangkan, mengasyikkan, dan mencerdaskan kurang optimal (Puspendik Depdiknas, 2006).

Penekanan pada aspek produk, menyebabkan siswa akan mengalami kesulitan untuk memahami penguasaan konsep IPA dengan baik. Jika hanya diuji tentang hal-hal yang terkait dengan fakta, mereka cenderung menghapal fakta saja, kondisi seperti ini tentunya tidak sesuai dengan pembelajaran IPA yaitu menguasai konsep-konsep IPA dan saling keterkaintannya serta mampu menggunakan metode ilmiah yang dilandasi sikap keilmuan untuk memecahkan masalah yang dihadapinya.

Pembelajaran IPA di sekolah bertujuan menguasai standar kompetensi yang telah ditetapkan, oleh karena itu pembelajaran IPA harus dibuat lebih menarik dan mudah dipahami, karena IPA lebih membutuhkan pemahaman dari pada penghafalan berbagai rumus yang begitu banyak. Untuk mengantisipasi hal tersebut salah satunya perlu di dukung sumber belajar serta model pembelajaran yang sesuai. Penggunaan model pembelajaran yang tepat diharapkan dapat 
membantu efektivitas proses pembelajaran serta penyampaian pesan dan isi pelajaran pada saat itu, selain itu juga akan memberikan pengertian konsep yang sebenarnya secara realistis.

Hasil observasi di SMPN 3 Satu Atap Cikulur hasil belajar IPA yang diperoleh siswa kelas VII berdasarkan pengalaman tahun-tahun sebelumnya perolehan skor nilai hasil belajar dari ulangan harian masih rendah, yaitu berkisar antara $40 \%$ sampai dengan $50 \%$ di bawah KKM (Kriteria Ketuntasan Minimal) yang sudah ditetapkan. Berarti hanya sekitar 50\% sampai dengan 60\% yang sudah tuntas.

Berdasarkan uraian di atas, dapat ditarik kesimpulan bahwa dalam pembelajaran IPA diperlukan model pembelajaran yang kreatif agar siswa mampu memecahkan masalah dengan mudah dan menguasai konsep serta memiliki motivasi belajar IPA. Model pembelajaran yang dibutuhkan haruslah terdapat variasi-variasi dalam penyampaian materi sehingga siswa dapat lebih memahami materi dan siswa mampu dengan mudah menguasai konsep serta memecahkan masalah dalam pelajaran IPA. Berdasarkan model pembelajaran yang ada, model pembelajaran yang menarik dan menyenangkan adalah melalui model pembelajaran Resource Based Learning (RBL).

Salah satu upaya yang tepat untuk meningkatkan kemampuan penguasaan konsep siswa adalah menerapkan model pembelajaran RBL. Pembelajaran RBL adalah pembelajaran dimana siswa dituntut untuk aktif dalam mencari berbagai macam sumber belajar (Nasution, 2013). Pada model pembelajaran ini, ditegaskan bahwa sumber belajar siswa tidak hanya pada satu sumber tetapi terdapat berbagai macam sumber belajar yang dapat mendukung proses belajar mengajar. Selama ini siswa belum sepenuhnya memanfaatkan seegala sumber belajar yang ada di sekolah sehingga pemahaman siswa dalam mencari sumber belajar masih terbatas. Jadi, dalam RBL guru bukan merupakan sumber belajar satu-satunya. Siswa dapat belajar dalam kelas, dalam laboratorium, dalam perpustakaan, dalam ruang sumber belajar yang khusus, atau bahkan di luar sekolah, bila ia mempelajari lingkungan berhubungan dengan tugas atau masalah tertentu.

Bertitik tolak pada hal tersebut diatas, maka penulis telah melakukan penelitian tentang penerapan model pembelajaran Resource Based Learning (RBL) dalam upaya meningkatkan kemampuan penguasaan konsep IPA pada siswa SMP.

\section{METODE}

Penelitian ini menggunakan Penelitian Tindakan Kelas (PTK), dimana peneliti berperan aktif sejak penyusunan perencanaan penelitian, pelaksanaan penelitian, hingga penyusunan laporan. Desain penelitian yang peneliti susun untuk kelancaran penelitian yang akan dilakukan digambarkan dalam diagram alur penelitian seperti pada Gambar 1.

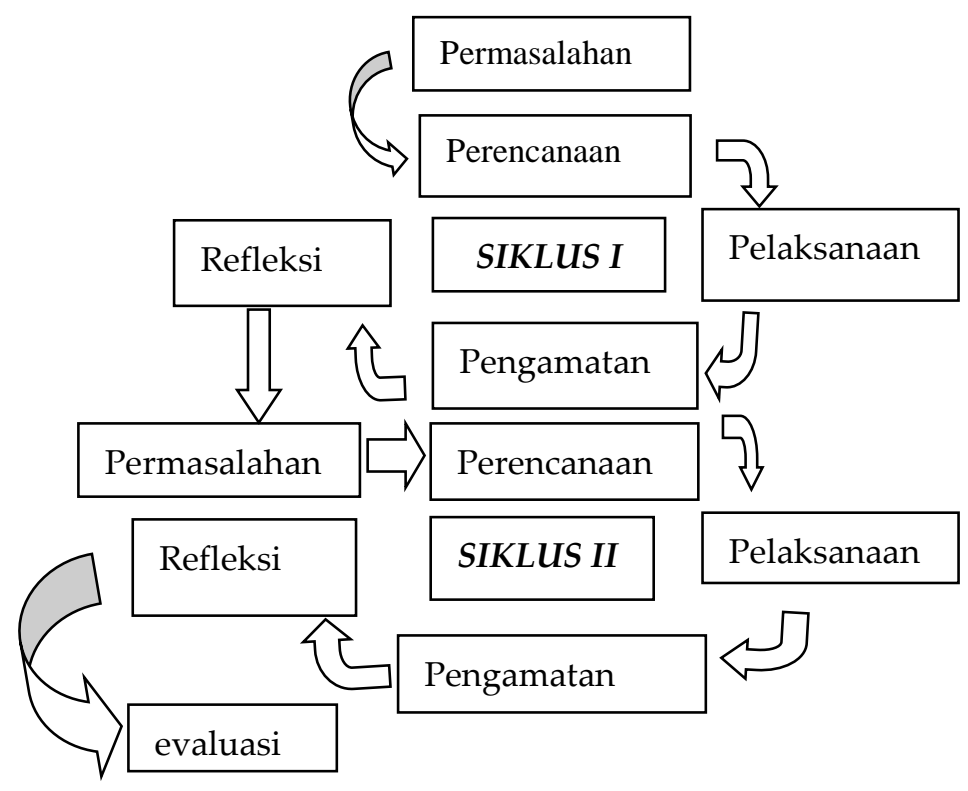

Gambar 1. Desain Penelitian Tindakan Kelas (Arikunto et al, 2008) 
Sumber data dalam penelitian ini adalah siswa kelas VII SMPN 3 Satu Atap Cikulur yang berjumlah 40 siswa yang terdiri dari 19 siswa laki-laki dan 21 siswa perempuan. Instrumen yang digunakan pada penelitian ini adalah lembar observasi, tes kemampuan penguasaan konsep IPA dan dokumentasi.

Teknis analisis data dalam penelitian ini menggunakan teknis analisis kulitatif, yang salah satu modelnya teknik analisis interaktif yang di kembangkan oleh Miles dan Huberman (dalam Kunandar, 2010) yang dilakukan sebagai berikut: 1) Reduksi data, 2) Display data, 3) Penarikan kesimpulan.

\section{HASIL DAN PEMBAHASAN}

\section{Hasil Pembelajaran dari Setiap Siklus}

Hasil Skor Tes Evaluasi Individu Siswa Siklus I setelah pembelajaran dengan menggunakan model pembelajaran RBL dapat dilihat pada Tabel 1.

Tabel 1. Hasil tes evaluasi individu siswa pada siklus I

\begin{tabular}{clcc}
\hline No & Keberhasilan & Jumlah Siswa & Persentase (\%) \\
\hline 1. & Tuntas & 19 & $47,5 \%$ \\
\hline 2. & Belum Tuntas & 21 & $52,5 \%$ \\
\hline & Jumlah & 40 & $100 \%$ \\
\hline
\end{tabular}

(sumber: olah data hasil tes evaluasi siswa siklus I)

Berdasarkan data Tabel 1 dapat dilihat bahwa siswa yang tuntas belajar mencapai 19 orang dan siswa yang belum tuntas belajar berjumlah 21 orang serta hasil tes evaluasi siswa pada siklus I nampak bahwa indikator yang ditetapkan belum mencapai target yang diharapkan, karena keberhasilan siswa secara klasikal adalah 47,5\%, masih jauh dari target ketuntasan klasikal yaitu $70 \%$, akan tetapi ada peningkatan walaupun tidak signifikan setelah pada sebelumnya nilai harian siswa sebelum dilakukan penelitian PTK, persentase ketuntasan siswa bernilai $40 \%$. Hal tersebut menunjukan peningkatan 7,5\% dari hasil siklus I.

Hasil Skor Tes Evaluasi Individu Siswa Siklus II setelah pembelajaran dengan menggunakan model pembelajaran RBL dapat dilihat pada Tabel 2.

Tabel 2. Hasil tes evaluasi individu siswa pada siklus II

\begin{tabular}{clcc}
\hline No & Keberhasilan & Jumlah Siswa & Persentase (\%) \\
\hline 1. & Tuntas & 29 & $72,5 \%$ \\
\hline 2. & Belum Tuntas & 11 & $27,5 \%$ \\
\hline & Jumlah & 40 & $100 \%$ \\
\hline
\end{tabular}

(sumber: olah data hasil tes evaluasi siswa siklus II)

Berdasarkan data Tabel 2 dapat dilihat bahwa siswa yang tuntas belajar mencapai 29 orang dan siswa yang belum tuntas belajar berjumlah 11 orang. Hasil tes evaluasi siswa tersebut pada siklus II sudah mencapai target yang diharapkan, karena keberhasilan siswa secara klasikal adalah $72,5 \%$, berarti sudah mencapai dan melebihi target ketuntasan klasikal yaitu $70 \%$. Pada hasil tes evaluasi siswa ada peningkatan signifikan setelah pada sebelumnya nilai tes evaluasi siswa pada siklus I, persentase ketuntasan siswa bernilai $47,5 \%$. Hal tersebut menunjukan peningkatan $25 \%$ dari hasil siklus II.

Hasil Tes Evaluasi Individu Siswa Siklus III dapat dilihat pada Tabel 3 di bawah ini.

Tabel 3. Hasil tes evaluasi individu siswa pada siklus III

\begin{tabular}{cccc}
\hline No & Keberhasilan & Jumlah Siswa & Persentase (\%) \\
\hline 1. & Tuntas & 34 & $85 \%$ \\
\hline 2. & Belum Tuntas & 6 & $15 \%$ \\
\hline & Jumlah & 40 & $100 \%$ \\
\hline
\end{tabular}

(sumber; olahan data hasil tes evaluasi siswa siklus III) 
Berdasarkan data Tabel 3 dapat dilihat bahwa siswa yang tuntas belajar mencapai 34 orang dan siswa yang belum tuntas belajar berjumlah 6 orang. Hasil tes evaluasi siswa tersebut pada siklus II sudah mencapai target yang diharapkan, karena keberhasilan siswa secara klasikal adalah $85 \%$, berarti sudah mencapai dan melebihi target ketuntasan klasikal yaitu $70 \%$. Pada hasil tes evaluasi siswa ada peningkatan signifikan setelah pada sebelumnya nilai tes evaluasi siswa pada siklus I, persentase ketuntasan siswa bernilai $72,5 \%$. Hal tersebut menunjukan peningkatan $12,5 \%$ dari hasil siklus III.

Penerapan model pembelajaran RBL dapat meningkatkan aktivitas siswa dalam belajar. Siswa terpacu dan tertantang untuk belajar secara aktif memanfaatkan sumber belajar yang ada. Siswa belajar dari upaya mereka sendiri berhadapan dengan berbagai sumber informasi sehingga mereka memperoleh keterampilan dalam mencari dan menggunakan informasi yang mereka pelajari. Hal tersebut dapat dibuktikan dan diperjelas dari hasil perolehan data observasi aktivitas siswa, yang tersaji di grafik 1 di bawah ini.

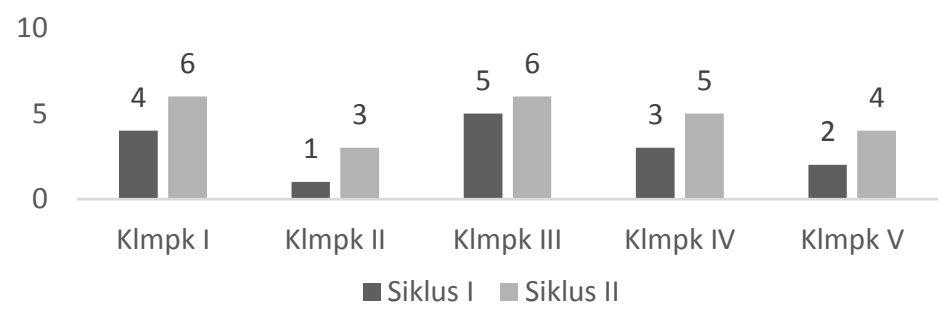

Gambar 2. Data Peningkatan Aktivitas Siswa pada Siklus I ke Siklus II (Sumber: olah data observasi aktivitas siswa pada siklus I dan II)

Melihat dari ketuntasan siswa, diperoleh data bahwa pada akhir siklus atau pada siklus III terdapat 34 siswa yang tuntas belajar dan 6 siswa yang belum tuntas. 6 siswa yang belum tuntas sebenarnya mengalami peningkatan pembelajaran namun relatif rendah dari kriteria ketuntasan belajar, faktor utama kenapa 6 siswa ini belum tuntas dikarenakan dari kemampuan siswa tersebut, siswa belum sepenuhnya berjuang belajar, siswa tersebut masih kurang percaya diri dengan kemampuan yang mereka miliki, dan siswa belum tuntas belajar masih ditemukan mengharapkan bantuan dari temannya bukan atas dasar kemampuannya sendiri. Untuk lebih jelasnya data peningkatan ketuntasan siswa dalam persentasi dapat dilihat dari grafik pada Gambar 3.

Nilai rata-rata siswa dari setiap siklus mengalami peningkatan dimulai dari tuntas belajar dari sebelum PTK ke Siklus I dengan yang tuntas belajar berjumlah 16 orang meningkat ke 19 orang dengan nilai rata-rata dari 61,38 menjadi 67,88. Kemudian dari siklus I ke siklus II dengan yang tuntas belajar berjumlah dari 19 orang meningkat ke 29 orang dengan nilai rata-rata dari 67,88 menjadi 74,69. Begitupun selanjutnya dari siklus II menuju siklus III menunjukan peningkatan dengan yang tuntas belajar berjumlah 29 orang meningkat ke 34 orang dengan nilai rata-rata dari 74,69 menguat menjadi 82,69 . Dari hasil di atas dapat disajikan peningkatan nilai rata-rata yang digambarkan dalam grafik pada Gambar 4.

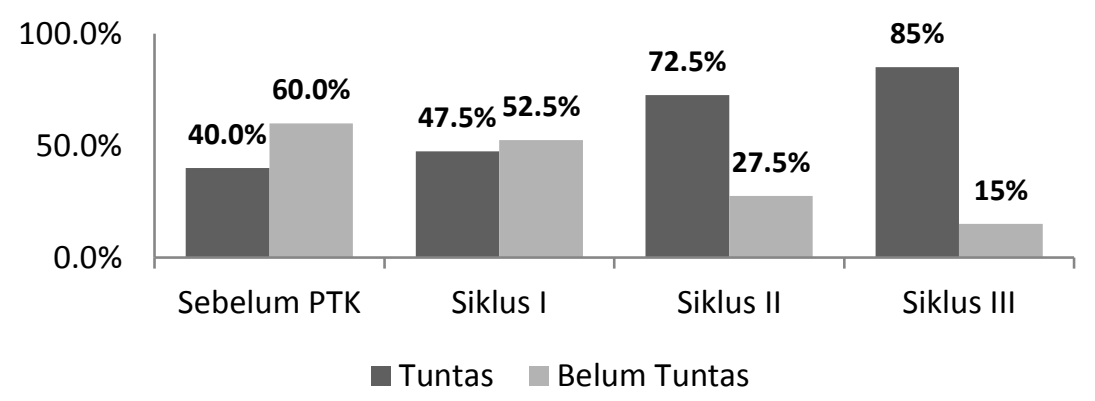

Gambar 3. Peningkatan Hasil Tes Siswa Pada Ketuntasan Belajar (Sumber: olahan data hasil tes evaluasi siswa dari setiap siklus) 


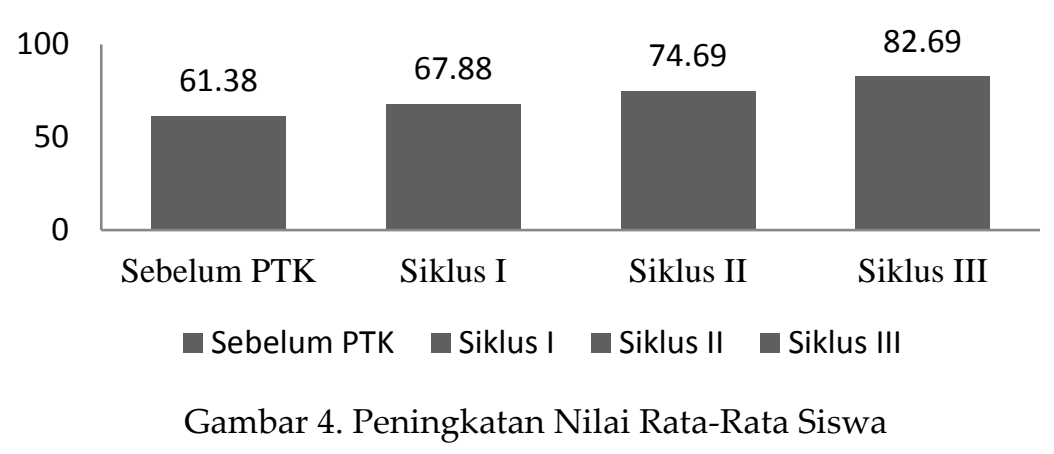

Berdasarkan Grafik 3 di atas, menunjukan adanya peningkatan nilai rata-rata siswa yang cukup baik, baik pada sebelum PTK ke siklus I maupun dari siklus I ke siklus II begitu pun juga pada siklus II ke siklus III.

\section{SIMPULAN}

Model pembelajaran Resource Based Learning (RBL) dapat meningkatkan kemampuan penguasaan konsep IPA siswa kelas VII. Peningkatan kemampuan penguasaan konsep siswa diperoleh dari hasil tes tindakan setiap siklus, dimana siklus I mencapai nilai rata-rata 67,88 dan siklus II mencapai nilai rata-rata 74,69 serta siklus III mencapai nilai rata-rata 82,69.

Model pembelajaran Resource Based Learning (RBL) sudah terlaksana sesuai dengan proses pembelajaran yang diharapkan di kelas dengan memanfaatkan sumber-sumber belajar yang tersedia di sekolah dan memberikan pemahaman baru kepada siswa untuk lebih terbuka dan memberikan wawasan supaya memanfaatkan segala sumber belajar yang terdapat di lingkungan sekolah.

Model pembelajaran Resource Based Learning (RBL) dapat meningkatkan aktivitas belajar siswa kelas VII. Model pembelajaran Resource Based Learning (RBL) dapat meningkatkan ketuntasan belajar siswa kelas VII. Hal ini dibuktikan dari hasil tes setiap siklus bahwa ketuntusan belajar siswa meningkat dari setiap siklusnya, dimana dalam siklus I ada 19 orang yang tuntas belajar dan siklus II ada 29 orang yang tuntas belajar serta siklus III ada 34 orang yang tuntas belajar dari 40 siswa.

\section{REFERENSI}

Arikunto,S., Suhardjono, \& Supardi. (2008). Penelitian Tindakan Kelas. Jakarta: Bumi Aksara.

Deporter, B., \& Hernacki, M. (2007). Quantum Learning, Membiasakan Belajar Nyaman dan Menyenangkan. (Alih Bahasa Alwiyah Abdurrahman). Bandung: Kaifa.

Kunandar. (2010). Langkah Mudah Penelitian Tindakan Kelas Sebagai Pengembangan Profesi Guru. Jakarta: Rajawali Pers.

Nasution, S. (2013). Berbagai Pendekatan Dalam Proses Belajar dan Mengajar. Jakarta: Bumi Aksara.

Depdiknas. (2006). Dalam Panduan Seminar Sehari Hasil Studi Internasional Prestasi Peserta Didik Indonesia di Bidang Matematika, Sains, dan Membaca. Jakarta: Puspendik Depdiknas.

Sanjaya, W. (2008). Perencanaan dan Desain Sistem Pembelajaran, Kencana Prenada Jakarta: Media Group. 